\title{
O Mistério da Encarnação na Cristologia de São Gregório de Nissa Um estudo sobre a filanthrōpía do Logos no LOGOS KATËCHËTIKOS (Oratio Catechetica Magna) XV
}

\author{
Orientador: Paulo Cezar Costa \\ Doutorando: Júlio Cesar Rocha dos Santos \\ Área de Concentração: Teologia Sistemático-Pastoral \\ Linha de Pesquisa: Fé e Cultura
}

A presente tese tem por objetivo estudar a filanthrōpía, a do Logos divino como motivo fundamental do mistério da Encarnação, na obra LOGOS KATĒCHĒTIKOS (Oratio Catechetica Magna) de São Gregório de Nissa, escrita no século IV na Capadócia (atual Turquia). Desenvolvido ao longo de quatro capítulos, o autor do presente estudo se propõe a pesquisar, nos dois primeiros, os pressupostos do tema da filanthrōpía do Logos. No terceiro, o estudo do tema se concentra sobre a obra focalizada de Gregório de Nissa, e no quarto, sobre algumas de suas outras obras. Nesse último, se faz referência ao vínculo existente entre a filanthrōpía do Logos, a oivkonomi,a salvífica e o mistério da Encarnação. Através de uma metodologia típica da Exegese Patrística, o autor da tese busca secundar suas reflexões com vários exemplos de trechos delas extraídos, comentá-los, e mesmo analisar vocábulos ou expressões da língua original em que foram escritos. Todo esse empenho o conduz a confirmar sua hipótese de que Gregório pretendeu tornar acessível o conteúdo desse mistério de fé ao pensamento e à linguagem dos catecúmenos, a cujos instrutores a obra fora escrita. Nesse sentido, a tese demonstra o quanto é atual a maneira como esse Padre da Igreja fez a leitura do tema, de modo a salientar mesmo o aspecto afetivo do mistério da Encarnação. Além disso, igualmente vem ressaltada a relação entre filanthrōpía do Logos e: o carisma da Inspiração, a Revelação ad intra do Ser ontológico de Deus, a moral social (mormente no que tange à sensibilidade para com os pobres), a vida batismal dos cristãos, o aspecto terapêutico e estético de sua ação. Por fim, a tese pretende contribuir, na atual Teologia do país, para um maior fomento no estudo do legado deixado pela Patrística.

Palavras-chave: Cristologia. Encarnação. Logos. 